Available online at GSC Online Press Directory

GSC Biological and Pharmaceutical Sciences

e-ISSN: 2581-3250, CODEN (USA): GBPSC2

Journal homepage: https://www.gsconlinepress.com/journals/gscbps

(RESEARCH ARTICLE)

\title{
Laboratory evaluation of toxicity of spinosad tablets and tracer 48 SC insecticides against different stages of American cockroaches (Periplaneta americana L.), in Jeddah governorate
}

\author{
Sharawi Somia ${ }^{1,}{ }^{*}$, Mahyoub Jazem ${ }^{1,2 *}$ and Assagaf Ahmad ${ }^{1}$ \\ ${ }^{1}$ Department of Biology Sciences, Faculty of Sciences, King Abdulaziz University, Jeddah, Saudi Arabia. \\ 2 IBB University, Ibb, Republic of Yemen.
}

Publication history: Received on 20 December 2018; revised on 14 January 2019; accepted on 18 January 2019

Article DOI: https://doi.org/10.30574/gscbps.2019.6.1.0163

\begin{abstract}
Periplaneta americana is an important household insect pest worldwide and acts as a mechanical vector and reservoir for pathogenic agents. Fermented insecticides are biopesticide, derived from fermentation by the soil-dwelling actinomycete. The aim of this study was to test the susceptibility of Spinosad tablets and Tracer 48 SC against $P$. americana adults and nymphs using different concentrations. Bioassays were done by feeding and contact toxicity methods. Mortality was recorded after 48 hours of exposure. Mortality data from the replicates was assessed by probit analysis. All tested insects showed high susceptibility for spinosad compared with the control. The effectiveness of fermented insecticides against susceptible different stages of $P$. americana showed that these formulations can be strongly effective for the control of P. americana.
\end{abstract}

Keywords: Spinosad; Tracer; Insecticides; Mortality; P. americana; Toxicity

\section{Introduction}

American cockroaches (Periplaneta americana) (Linnaeus), order Dictyoptera, suborder Blattaria is an important insects in medical [1], they are the most notorious pests, found in kitchens [2]. It is one of the largest common cockroach species [3]. Out of 500, 30 species are considered as household pest [4]. A number of cockroaches pests live in/or around homes, and they are omnivorous scavengers [1]. They survive in warm weather with high moisture conditions as well as in unfavorable environments for humans [5].

P. americana can spread bacteria, fungi, and other pathogenic microorganisms from infected areas [6], and cause allergies to human [7]. They play important role in the transmission of different diseases by mechanical and biological ways $[8,9]$. P. americana spends most of its time in sewage, sewer pipe which usually contains high density of pathogens [10]. Also, they feed on garbage and they have large opportunities to disseminate human pathogen [11, 12]. In addition, their nocturnal and filthy habits of eating their feces make them ideal carriers of numerous pathogenic microbes [13]. Cockroaches spread pathogens through their cuticle [14], because their nymphal cuticles go through ecdysis [15]. Therefore, they transfer pathogens in different ways such transmission routes may occur among populations with infected individuals such as vertical transmission which occurs when an infected mother passes on the pathogen or disease to her progeny [16]. All of these pathogens used as dangerous organisms targeting animal or human populations.

A numerous pathogens such as bacteria, fungi and molds, helminths, protozoans and viruses, harmful to humans being are carried by cockroaches as well as they present in their faeces $[12,17]$. More than 100 species of bacteria have been

\footnotetext{
${ }^{*}$ Corresponding author

E-mail address: sesharawi@kau.edu.sa
}

Copyright (C) 2019 Author(s) retain the copyright of this article. This article is published under the terms of the Creative Commons Attribution Liscense 4.0. 
isolated from domestic cockroaches [18], out of which, a few could be potential mechanical transmitters of pathogenic bacteria [19]. In addition more than 40 pathogenic and nonpathogenic bacterial species have been isolated from cockroaches. Moreover, 70 species of Gram positive and negative bacteria belonging to 37 genera were isolated from the surface and fecal pellets; including: Actinomyces randingae, Alcaligenes faecalis, Arthrobacter cumminnsii, Aureubacterium spp., Bacillus spp., Brevibacterium spp., Burkholderia vietnamiensis, Buttiauxella sp., Citrobacter sp., Corynebacterium spp., Enterobacter spp., Erwinia sp., Escherichia coli, Hafnia sp., Kigali sp., Klebsiella spp., Kluyvera sp., Kauri rosea, Leuconostoc sp., Micro bacterium spp., Micrococcus sp., Proteus spp., Providence ruttier, Pseudomonas spp., Rhodococcus australis, Rhodococcus rhodochrous, Salmonella typhimurium, Serratia spp., Shigella sp., Spingobacterium thalpophilum, Staphylococcus spp., Stenotrophomonas maltophillia, Streptococcus sp., Tsukamurella inchonensis, Vibrio metschnikovii, Xanthomonas spp., Entamoeba histolytica, Escherichia coli, Klebsiella pneumoniae, Mycobacterium leprae, Shigella dysenteriae, and Salmonella sp., including Salmonella typhi and Salmonella typhimurium, Serratia species, Staphylococcus aureus and Aeromonas sp. [14].

Many parasites have been isolated from cockroaches e.g., cysts of Entamoeba histolitica, oocysts of Cryptosporidium parvum, Cyclospora cayetanensis and Isospora belli, cysts of Balantidium coli, ova of Ascaris lumbricoides, Anchylostoma deodunale, Enterobius vermicularis, ovae Trichuris trichura and larvae of Strongyloides stercoralism [20].

A number of fungal species have been isolated from both the external body parts as well as faecal of cockroaches such as Candida spp., Rhodotrula spp., Aspergillus spp., Fusarium spp., Penicillium spp. and Geotrichum spp. were appeared on external surfaces of cockroaches. Other medically important mold, Alternaria spp., Cladosporium spp., Trichoderma spp., Mucor spp. and Chrysosporium spp. have been isolated from a few cockroaches, Chrysosporium glabrata and Chrysosporium albicans were the highest species isolated from cockroaches. Chrysosporium parapsilosis and Chrysosporium guilliermondii were present on the external surfaces in a few cockroaches. In addition, three species of Aspergillus have been identified via molecular characterization. Aspergillus niger was common and frequently isolated species from cockroaches. However, A. fumigatus and A. flavus were isolated from the external surface a few cockroaches. A total of 6 samples were found to carry two species of Aspergillus on their external surfaces [20, 21].

Helminths have also been reported in cockroaches collected from different areas [22], being widely implicated as reservoir hosts of medically important parasites [23, 24]. Pathogenic helminths included Strongyloides stercoralis, Ascaris lumbricoides, Trichuris trichiura and Taenia spp. [25]. The cockroaches are also implicated in the spread of at least some pathogens like hepatitis $[12,15,26]$.

Protozoa types that were identified from cockroaches included Cyclospora spp., Endolimax nana, Blastocystis hominis, Isospora belli, Entamoeba histolytica, Cryptosporidium spp., Chilomastix mesnilli, Entamoeba coli, Balantidium coli and Iodamoeba butschlii [25].

The control of $P$. americana can be done by applying insecticides to the hiding and resting places in the form of insecticidal dusts and residual sprays. Chemical control has been the most popular and effective method so far [27], but their control as insecticides is not a suitable because of several reasons; the most important of which is that they may develop resistance against certain frequently used insecticides [28]. Conventional or non-conventional insecticides were used against P. americana exhibited a high efficiency in controlling the insect pest [29].

Biological insecticides such as microbes, do not pose a disease risk to wildlife, humans, and other organisms not closely related to target insect $[30,31,32]$. Several new chemical substances with low mammalian toxicity have been evaluated for this purpose in several parts of the world, aiming to gradually replace the use of conventional insecticides, such as the organophosphorates (OPs) [33]. For instance, some pyrethroids have been successfully used as alternatives to OPs [34]. Spinosad, which is based on the metabolites from the actinomycete Saccharopolyspora spinosa, appears to be one of the most promising new grain protectants [35]. Spinosad has low mammalian toxicity and acts on the insects' nervous system, by ingestion or contact [34].

Spinosad is microbes that can be fermented to produce an insecticide such as abermectins, a fermented product of Streptomyces avermitilis used in baits for household insect pests. The best-known home gardening product of this type is spinosad. It composed of spinosyns A and D. The fermented product is very toxic to caterpillar pests such as cabbageworm, cabbage looper, diamondback moth, armyworm, and cutworm, as well as fruit flies such as spotted wing drosophila. Spinosad can act on a susceptible insect's stomach and nervous system. It is primarily ingested by feeding insects but can have some efficacy when sprayed directly on insects. Affected pests cease feeding and undergo partial paralysis within minutes upon exposure to spinosad, but it may take up to two days for the insects to die [36]. It has low toxicity to many beneficial insects that prey on pests and is nontoxic to mammals and other vertebrates, with the 
exception of some fish. Because it is selectively toxic for many pest species and relatively safe to non-target species, spinosad has become highly desirable as an organic insecticide. Spinosyn A affect because it is effect on the involuntary muscle contractions and tremors by widespread excitation of neurons in the central nervous system and caused excitation when applied directly to isolated insect ganglia at submicromolar concentrations. Prolonged spinosyninduced hyperexcitation resulted in paralysis that was associated with neuromuscular fatigue [36].

Much of the work regarding insecticidal efficacy has been done on B. germanica, however, very little data is available with respect to $P$. americana. Therefore, keeping in view the work carried out by various researchers, the present work was designed to investigate the insecticidal efficacy of formulations of fermented insecticides against $P$. americana, and the susceptibility of different stages to these insecticides through laboratory bioassay using feeding and contact toxicity methods.

\section{Material and methods}

\subsection{Experimental insect}

P. americana was collected from dark and damp places (sewers) from different areas in Jeddah province by using food jars surrounded by dark cloth as a trap [37]. The strains were stored in the lab and used in this study. Traps were placed into main sewers. Cockroaches were collected every two days and placed in glass containers $(30 \times 60 \times 30 \mathrm{~cm})$. Then, they were thus kept under the laboratory condition of $25 \pm 3^{\circ} \mathrm{C}$ and $75 \pm 5 \% \mathrm{RH}$.

\subsection{Chemicals}

The present study was designed to investigate the insecticidal efficacy of two different fermented insecticides: Spinosad tablets and Tracer 48 SC. The choice of these formulations was based on the fact that those chemicals have not been tested against different stages of $P$. americana in Jeddah governorate so far. All chemicals were obtained from Machinery \& Agricultural Materials Co., Ltd, Jeddah, Saudi Arabia.

Insecticides were tested against $P$. americana adult and nymphs by feeding and contact toxicity methods, different concentrations were prepared and mortality percentages were recorded after $48 \mathrm{~h}$.

\subsection{Feeding bioassay}

Feeding bioassay was done according to [38], with some modifications against adults and nymphs. For the present study, Bait was improvised in the laboratory. Feeding bioassays were conducted with lab strains using previous plastic boxes coated with petroleum jelly $2 \mathrm{~cm}$ from the inside top to prevent the cockroaches from escaping. $1 \mathrm{gm}$ of white floor, $1 \mathrm{gm}$ of powder milk, $1 \mathrm{gm}$ of sugar were prepared manually and treated with different concentrations of insecticides and appropriate amount of water to make semisolid bait. A single pellet was large enough to be entirely eaten by adults or nymphs starved for $24 \mathrm{~h}$. Treated pellets were dried in a fume hood for 15-20 min. A single pellet was then provided to adults and nymphs held in approximately 3-4 gm. Control insects received treated pellets only with water. Each replicate consisted of 30 insects and three replicates for each concentration. Mortality was assessed at 48 h.

\subsection{Contact toxicity bioassay}

Contact toxicity bioassay was done according to [39], with some modifications against adults and nymphs. Contact toxicity mixture was improvised in the laboratory. Contact bioassays were conducted with previous method. Liquid mixture was then conducting by spraying different concentrations of the insecticide from inside plastic box and make sure that the insecticide covered all the sides. Three plastic boxes with 30 cockroaches (adults and nymphs) were used for each concentration.

\subsection{Statistical analysis}

This study was completely randomized design (CRD) in a factorial experiment. The data were statistically analyzed using analysis of variance (ANOVA). $\mathrm{LC}_{50}$ and $\mathrm{LC}_{90}$ were calculated according to Probit analysis program [40]. All Malformations were captured using digital camera. 


\section{Results}

Feeding bioassay of Spinosad tablets was resulted in Table 1 and Fig. 1 against $P$. americana adults and nymphs after 48 h., of exposure periods and the results shows that low concentrations exhibited high mortality to adults and nymphs $(100.00 \%)$ at the highest concentration of 5\% and 3\%, respectively. The nymphs were more sensitive to Spinosad tablets by $\mathrm{LC}_{50}$ 's values $(0.019 \%)$ followed by adults $(0.065 \%)$ after 48 h., for contact toxicity bioassay with Spinosad tablets, there was positive correlation between mortality of Spinosad tablets concentrations and exposure intervals.

Mortality of adults and nymphs resulted after feeding bioassay with Tracer 48SC was summarized in Table 2 and Fig. 2. Mortality percentage were highly increased by increasing concentrations at all exposure intervals for adults and nymphs. After 48 h., Tracer 48SC gave high level of mortality to adults and nymphs (96.66\%) at low concentrations. In the susceptibility level of nymphs and adults of $P$. americana after $48 \mathrm{~h}$., the nymphs were more sensitive to Tracer $48 \mathrm{SC}$ by $\mathrm{LC}_{50}$ values $(0.068 \%)$ than adults $(0.097 \%)$ after $48 \mathrm{~h}$. For contact toxicity method, also there was positive correlation between mortality of Tracer 48SC concentrations and exposure intervals.

Table 1 Susceptibility adults and nymphs of $P$. americana to Spinosad tablets using feeding and contact toxicity methods after $48 \mathrm{~h}$

\begin{tabular}{|c|c|c|c|c|c|c|c|c|}
\hline \multirow{3}{*}{ Treatment } & & \multicolumn{7}{|c|}{ Parameters } \\
\hline & & \multirow{2}{*}{$\begin{array}{l}\text { Concentration } \\
(\%)\end{array}$} & \multirow{2}{*}{$\begin{array}{l}\text { Mortality } \\
\text { (\%) }\end{array}$} & \multirow{2}{*}{$\begin{array}{l}\mathrm{LC}_{50} \\
(\mathrm{~L}-\mathrm{U})\end{array}$} & \multirow{2}{*}{$\begin{array}{l}\text { LC90 } \\
(\mathrm{L}-\mathrm{U})\end{array}$} & \multicolumn{2}{|c|}{$\mathbf{X}^{2 *}$} & \multirow{2}{*}{ Slope } \\
\hline & & & & & & Calculated & Tabulated & \\
\hline $\begin{array}{l}\text { Adult } \\
\text { Feeding }\end{array}$ & / & $0.01-5$ & $26.66-96.66$ & $\begin{array}{l}0.065 \\
(0.046-0.088)\end{array}$ & $\begin{array}{l}1.921 \\
(1.307-3.096)\end{array}$ & 2.456 & 11.1 & 0.873 \\
\hline $\begin{array}{l}\text { Adult } \\
\text { Contact }\end{array}$ & / & $0.0001-0.5$ & 13.33-93.33 & $\begin{array}{l}0.0018 \\
(0.0013-0.0024)\end{array}$ & $\begin{array}{l}0.062 \\
(0.0405-0.1046)\end{array}$ & 3.897 & 12.6 & 0.832 \\
\hline $\begin{array}{l}\text { Nymph } \\
\text { Feeding }\end{array}$ & / & $0.01-1$ & $43.33-96.66$ & $\begin{array}{l}0.019 \\
(0.010-0.028)\end{array}$ & $\begin{array}{l}0.698 \\
(0.418-1.464)\end{array}$ & 5.232 & 9.5 & 0.816 \\
\hline $\begin{array}{l}\text { Nymph } \\
\text { Contact }\end{array}$ & / & $0.0001-0.1$ & $26.66-96.66$ & $\begin{array}{l}0.001 \\
(0.0004-0.0019)\end{array}$ & $\begin{array}{l}0.063 \\
(0.0322-0.2785)\end{array}$ & 11.84 & 11.1 & 0.709 \\
\hline
\end{tabular}

$\mathrm{LC}_{50}=$ lethal concentration that kill $50 \%$ of the treated insects, $\mathrm{LC}_{90}=$ lethal concentration that kill $90 \%$ of the treated insects, U: upper limit, $\mathrm{L}$ : lower limit,

$* \mathrm{X}^{2}=$ Chi square, When tabulated $(\mathrm{Chi})^{2}$ larger than calculated at 0.05 level of significance indicates the homogeneity of results.

Table 2 Susceptibility adults and nymphs of $P$. americana to Tracer 48SC using feeding and contact toxicity methods after $48 \mathrm{~h}$

\begin{tabular}{|c|c|c|c|c|c|c|c|}
\hline \multirow{3}{*}{ Treatment } & \multicolumn{7}{|c|}{ Parameters } \\
\hline & \multirow{2}{*}{$\begin{array}{l}\text { Concentration } \\
(\%)\end{array}$} & \multirow{2}{*}{$\begin{array}{l}\text { Mortality } \\
(\%)\end{array}$} & \multirow{2}{*}{$\begin{array}{l}\mathrm{LC}_{50} \\
(\mathrm{~L}-\mathrm{U})\end{array}$} & \multirow{2}{*}{$\begin{array}{l}\text { LC90 } \\
(\mathrm{L}-\mathrm{U})\end{array}$} & \multicolumn{2}{|c|}{$\mathrm{X}^{2 *}$} & \multirow{2}{*}{ Slope } \\
\hline & & & & & Calculated & Tabulated & \\
\hline Adult / Feeding & $0.01-3$ & $20-96.66$ & $\begin{array}{l}0.097 \\
(0.0719-0.1282)\end{array}$ & $\begin{array}{l}2.178 \\
(1.4086-3.8346)\end{array}$ & 8.372 & 11.1 & 0.949 \\
\hline Adult / Contact & 0.0001-0.1 & $26.66-96.66$ & $\begin{array}{l}0.0007 \\
(0.0005-0.001)\end{array}$ & $\begin{array}{l}0.034 \\
(0.0216-0.0608)\end{array}$ & 1.35 & 12.6 & 0.756 \\
\hline $\begin{array}{l}\text { Nymph } \\
\text { Feeding }\end{array}$ & $0.01-3$ & $23.33-96.66$ & $\begin{array}{l}0.068 \\
(0.0476-0.0936)\end{array}$ & $\begin{array}{l}2.128 \\
(1.2976-4.1411)\end{array}$ & 2.365 & 9.5 & 0.858 \\
\hline $\begin{array}{l}\text { Nymph } \\
\text { Contact }\end{array}$ & $0.0001-0.01$ & $40-96.66$ & $\begin{array}{l}0.0003 \\
(0.0002-0.0004)\end{array}$ & $\begin{array}{l}0.0064 \\
(0.004-0.012)\end{array}$ & 4.792 & 9.5 & 0.919 \\
\hline
\end{tabular}

$\mathrm{LC}_{50}=$ lethal concentration that kill $50 \%$ of the treated insects, $\mathrm{LC}_{90}=$ lethal concentration that kill $90 \%$ of the treated insects, U: upper limit, L: lower limit,

$* \mathrm{X}^{2}=$ Chi square, When tabulated (Chi) $)^{2}$ larger than calculated at 0.05 level of significance indicates the homogeneity of results 


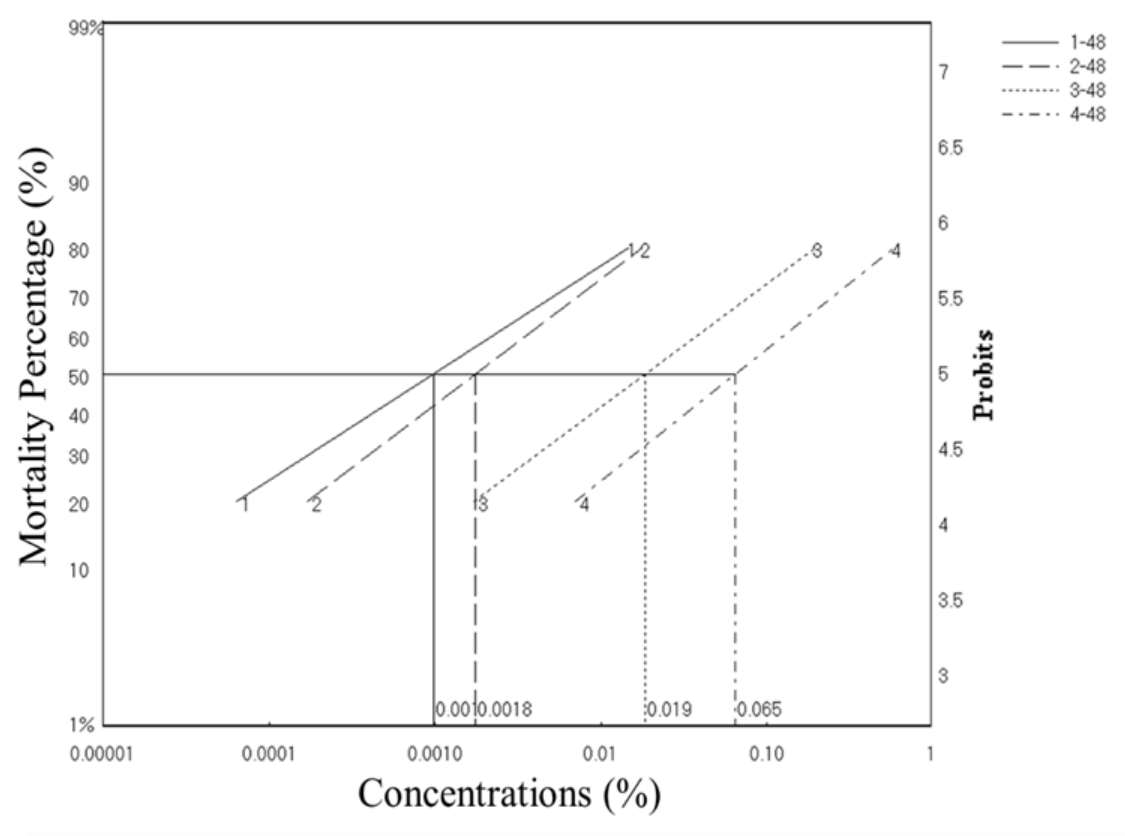

Figure 1 Susceptibility adults and nymphs of $P$. americana to Spinosad tablets using feeding and contact toxicity methods after $48 \mathrm{~h}$

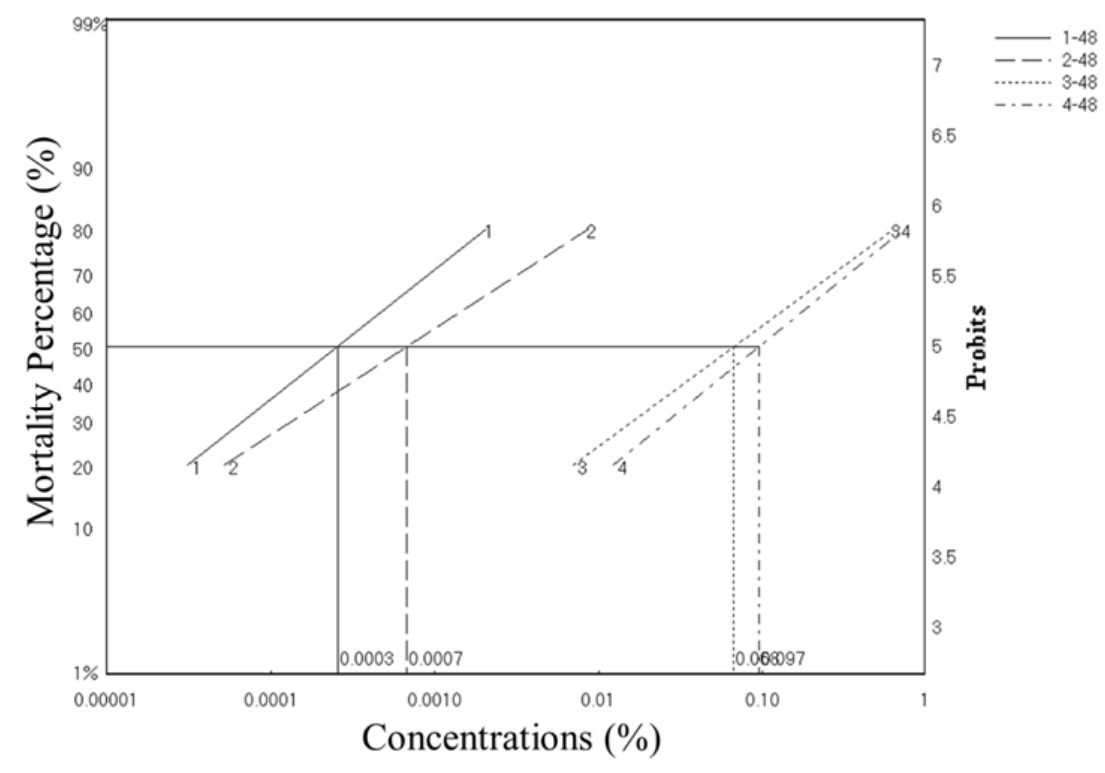

Figure 2 Susceptibility adults and nymphs of $P$. americana to Tracer 48SC using feeding and contact toxicity methods after $48 \mathrm{~h}$

\section{Discussion}

The modes of action of fermented insecticide have not been documented, but it kills a wide range and variety of insect pests when it ingested or topically applied to control [41], and they exhibited broad-spectrum activity against insect species in different orders, especially Lepidoptera and DipteraIn [42]. In our finding, spinosad tablets and Tracer showed high mortality for both adults and nymphs with continuous nervous effects. Similar to our results, [43], showed that the spinosad exhibits a high level of toxicity with a dose-response relationship, and the determined $\mathrm{LC}_{50}$ revealed a neurotoxic activity of spinosad. The results match those observed in earlier studies by [44], who mentioned that 
insecticidal spinosyns have potent effects on the function of the GABA receptors of small-diameter cockroach neurons and can elicit a small-amplitude $\mathrm{Cl}^{-}$current. In another study, [33], examined the insecticidal effect of spinosad, against adults of the lesser grain borer, Rhyzopertha dominica, the rice weevil, Sitophilus oryzae, the confused flour beetle, Tribolium confusum Jacquelin on wheat and the larger grain borer, Prostephanus truncatus on maize and he found that $R$. dominica and P. truncatus were very susceptible to spinosad, followed by S. oryzae, while T. confusum was the least susceptible. The insecticidal mode of action of fermented insecticides are not completely understood, but is considered unique in comparison with other insecticides. It has been demonstrated their interaction with g-aminobutyric acid receptors and nicotinic acetylcholine receptors, eventually leading to the disruption of neuronal activity and consequent insect paralysis and death [45]. Our selective insecticides have not been used before in the control of different stages of P. americane in Jeddah governorate, but other formulations from the same class have been tested against other insects in other areas. Spinosad or Success ${ }^{\circledR}$ is the first member of the fermented insectcides, and it was first introduced for control of diamondback moth (DBM), Plutella xylostella, in Asia [46]. Spinosad appeared to be effective against the pest on aubergines. In field tests on onion, lambda-cyhalothrin and fipronil were highly effective on $T$. tabaci. The effect of spinosad on thrips in cotton was studied by [47]. In other study, field trial on efficacy of spinosad against vegetable pests was conducted by [48], they found that the foliar application of spinosad can control thrips in leeks and salad onion as well as caterpillar pests in head and flowering brussels sprouts. [49], investigated the bioefficacy of eight different insecticides based on four active substances in 2002 in Slovenia and found that spinosad and abamectin exhibited the highest efficiency against T. tabaci. [50], evaluated some newer insecticides for control of pomegranate fruit borer at Mahatma Phule Krishi Vidyapeeth, Rahuri (MS), India, by spraying spinosad 45 SC and it was effective. [51], conducted a field experiment at Dharwad, Karnataka, India to evaluate the efficacy of different insecticides against sucking pests of okra and they found that spinosad $45 \mathrm{SC}$ was the most effective against thrips.

\section{Conclusion}

The present study revealed that Spinosad Tablets and Tracer 48SC were toxicity and can be used as a biological control against $P$. americana adults and nymphs in Jeddah governorate.

\section{Compliance with ethical standards}

\section{Acknowledgments}

The authors express their sincere gratitude to the Dengue Mosquito Experimental Station (DMES), belonging to the Department of Biological Sciences, Faculty of Sciences, King Abdul-Aziz University, Jeddah, Saudi Arabia for providing necessary equipments and their nice cooperating throughout the research period.

\section{Disclosure of conflict of interest}

It has to be declared that the authors of the study have no conflict of interest among them.

\section{References}

[1] Akbari S, Mohammad AO, Saedeh SH, Sara H, Ghazaleh O and Mohammad HS. (2015). Aerobic Bacterial Community of American Cockroach Periplaneta americana, a Step toward Finding Suitable Paratransgenesis Candidates. J Arthropod Borne Dis, 9(1), 35-48.

[2] El-Sherbini G and Gneidy MR. (2012). Cockroaches and Flies in Mechanical Transmission of Medical Important Parasites in Khaldyia Village, El-Fayoum, Governorate, Egypt.

[3] Gary A. (2015). Museum of Comparative Zoology, Harvard University. Integrated Pest Management Program, Cornell University.www.nysipm.cornell.edu/factsheets/buildings/german_cockroach.pdf

[4] Chung HS, Yu TH, Kim BJ, Kim SM, Kim JY and Yu HS. (2005). Expressed sequence tags analysis of Blattella germanica. Kor J Parasitiol, 43, 149-156.

[5] Jaramillo-Ramirez GI, Cárdenas-Henao H, González-Obando R and Rosero-Galindo CY. (2010). Genetic variability of five Periplaneta americana L. (Dyctioptera: Blattidae) populations in southwestern Colombia using the AFLP molecular marker technique. Neotrop Entomol, 39, 371-378. 
[6] Czajka E, Pancer K, Kochman M, Gliniewicz A, Sawicka B, Rabczenko D and Stypulkowska- Misiurewicz H. (2013). Characteristics of bacteria isolated from body surface of German cockroaches caught in hospitals. Przegl. Epidemiol, 57, 655-662.

[7] Kinfu A and Erko B. (2008). Cockroaches as carriers of human intestinal parasites in two localities in Ethiopia.Trans R Soc Trop Med Hyg, 102, 1143-1147.

[8] Malik K, Jamil A and Arshad A. (2013). Study of pathogenic microorganisms in the external body parts of American cockroach (Periplanata americana) collected from different kitchens. I OSR J Pharm Biol Sci, 7(6), 4548.

[9] Kim I, Lee JH, Subramaniyam S, Yun E and Kim I. (2016). De Novo Transcriptome Analysis and Detection of Antimicrobial Peptides of the American Cockroach Periplaneta americana (Linnaeus). PLoS One, 11, 5.

[10] Basseri HR, Amir DK, Ronak B, Mandan A and Reza HB. (2016). Isolation and Purification of an Antibacterial Protein from Immune Induced Haemolymph of American Cockroach, Periplaneta americana. Journal of arthropod-borne diseases, 10, 519-27.

[11] Cotton MF, Wasserman E, Pieper CH, Van TD, Campbell G, Fang FC and Barnes J. (2000). Invasive disease due to extended spectrum beta-lactamase-producing Klebsiella pneumoniae in a neonatal unit: the possible role of cockroaches. J Hosp Infect, 44, 13-17.

[12] Pai HH, Chen WC and Peng CF. (2005). Isolation of bacteria with antibiotic resistance from household cockroaches (Periplaneta americana and Blatella germanica). Acta Tropica, 93, 259-265.

[13] Allen BW. (1987). Excretion of viable tubercle bacilli by Blatta orientalis (the oriental cockroach) following ingestion of heat-fixed sputum smears: a laboratory investigation. Trans R Soc Trop Med Hyg, 81, 98-99.

[14] Mpuchane S, Matsheka IM, Gashe BA, Allotey J, Murindamombe G and Mrema N. (2006b). Microbiological studies of cockroaches from three localities in Gaborone, Botswana. Afr J Food Nutr Sci, 6.

[15] Mpuchane S, Allotey J, Matsheka I, Simpanya M, Coetzee S, Jordaan A, Mrema N and Gashe BA. (2006a). Carriage of micro-organisms by domestic cockroaches and implications on food safety. Int J Trop Insect Sci, 26, 166-175.

[16] Jennifer LP. (2008). intraspecific gene flow and vector competence among Periplaneta americana cockroaches (Blattodea: Blattidae) in central Texas. Texas A\&M University, 218, 3524927.

[17] Allotey J, Mpuchane S, Gashe BA, Simpanya M and Matsheka I. (2009). Trapping of Blattella germanica (L) populations in human dwellings in Gaborone, Botswana. J Appl Zoo Res, 20(2), 175-188.

[18] Cruden DL and Markovetz AJ. (1987). Microbiological study of domestic cockroaches in microbial ecology of the cockroach gut. Annual review of human dwelling localities. Annu Rev Microbiol, 41, 617- 643.

[19] Pai HH. (2013). Multidrug resistant bacteria isolated from cockroaches in long-term care facilities and nursing homes. Acta Trop, 125, 18-22.

[20] Adeleke MA, Akatah HA, Hassan AWO and Adebimp WO. (2012). Microbial load and multiple drug resistance of pathogenic bacteria isolated from faeces and body surfaces in an urban area of southwestern. J Microbiol Biotechnol Food Sci, 1, 1448-1461.

[21] Motevali HSF, Aghili S, Gholami Sh, Salmanian B, Nikokar SH, Khangolzadeh GM and Hajati H. (2014). Isolation of medically important fungi from cockroaches trapped at hospitals of Sari, Iran. Bulletin of Environment, Pharmacology and Life Sciences, 3, 29- 36.

[22] Etim SE, Okon OE, Akpan PA, Ukpong GI and Oku EE. (2013). Prevalence of cockroaches (Periplanata americana) in households in Calabar: public health implications. J Public Health Epidemiol, 5, 149-152.

[23] Chan OT, Lee TK, Hardman JM and Navin JJ. (2004). The cockroach as a host for Trichinella and Enterobius vermicularis: implications for public health. Hawaii Med J, 63, 74-77.

[24] Thyssen PJ, Moretti TC, Ueta MT and Ribeiro OB. (2004). The role of insects (Blattodea, Diptera and Hymoptera) as possible mechanical vectors of helminths in the domiciallary and pre-domicilliary environment. Cad Saude Publica, 20, 1096-1102.

[25] Chamavit P, Panupong S and Nunthawadee N. (2011). The majority of cockroaches from the Samutprakarn province of Thailand are carriers of parasitic organisms. EXCLI journal, 10, 218-22. 
[26] Karimi ZAA and Vatani HA. (2009). Survey on species and prevalence rate of bacterial agents isolated from cockroaches in three hospitals. Vector-Borne and Zoonotic Diseases, 9, 197-200.

[27] Lee CY and Robinson W. (2001). Handbook of Malaysian household and structural pests. Pest Control Association of Malaysia, Kuala Lumpur, Malaysia, 96-108.

[28] Tsai C and Lee H. (2001). Analysis of specific adaptation to a domicile habitat: A comparative study of two closely related cockroach species. J Med Entomol, 38, 245-252.

[29] Khattak MK and Mamoon-ur-Rasheed SAS. (2006). Comparative effect of neem (Azadirachta indica A. Juss) oil, neem seed water extract and baythroid TM against whitefly, jassid and thrips on cotton. Pak. Entomol, 28(1), 3137.

[30] Sarwar M. (2010). Some possibilities on the effectiveness of plant powders as grain protectants against cowpea weevil, Callosobruchus maculatus (Fabricius) Walp (Coleoptera: Bruchidae) infestation in chickpea. International Journal of Agronomy and Plant Production, 1 (2), 45-50.

[31] Sarwar M. (2012), Competency of Natural and Synthetic Chemicals in Controlling Gram Pod Borer, Helicoverpa armigera (Hubner) on Chickpea Crop. International Journal of Agricultural Sciences, 2 (4), 132-135.

[32] Sarwar M. (2013). The inhibitory properties of organic pest control agents against aphid (Aphididae: Homoptera) on Canola Brassica napus L. (Brassicaceae) under field environment. International Journal of Scientific Research in Environmental Sciences, 1 (8), 195-201.

[33] Athanassiou CG, Kavallieratos NG, Yiatilis E, Vayias BJ, Mavrotas CS and Tomanović Ž. (2008). Influence of temperature and humidity on the efficacy of spinosad against four stored-grain beetle species. J Insect Sci, 8(1), 60.

[34] Subramanyam BH. (2006). Performance of spinosad as a stored grain protectant. Proceedings of the $9^{\text {th }}$ International Working Conference for Stored-Product Protection, 250-257.

[35] Thompson GD, Michel KH, Yao RC, Mynderse JS, Mosburg CT, Worden TV, Chio EH, Sparks TC and Hutchins SH. (1997). The discovery of Saccharopolyspora spinosa and a new class of insect control products. Down to Earth, 52, 1-5.

[36] Salgado VL. (1998). Studies on the Mode of Action of Spinosad: Insect Symptoms and Physiological Correlates. Pesticide Biochemistry and Physiology, 60 (2), 91-102.

[37] Wang C and Bennett GW. (2006). Comparative study of integrated pest management and baiting for German cockroach management in public housing. J Econ Entomol, 99, 879-85.

[38] Gondhalekar AD and Scharf ME. (2013). Preventing resistance to bait products, 42-46.

[39] Ling I, Sulaiman S and Othman H. (2009), Evaluation of Piper aduncum Linn. essential oil (Fam: Piperaceae) against Periplaneta americana (L.). Iran J Arthropod Borne Dis, 3(2), 1-6.

[40] Finney DJ. (1972). Probit Analysis: A Statistical Treatment of the Sigmoid Response Curve. $7^{\text {th }}$ Edition, Cambridge University Press, Cambridge, 33.

[41] Habbachi W, Bensafi H, Adjami Y, Ouakid ML, Farine JP and Everaerts C. (2009). Spinosad affects chemical communication in the German cockroach, Blatella germanica (L). J Chem Ecol, 35(12), 1423-6.

[42] Kirst HA. (2010). The spinosyn family of insecticides: Realizing the potential of natural products research. J Antibiot, 101-111.

[43] Samir T, Tine-Djebbar F, Aribi N and Hamid B. (2015). Topical toxicity of spinosad and its impact on the enzymatic activities and reproduction in the cockroach Blatta orientalis (Dictyoptera: Blattellidae). African Entomology, 23, 387-396.

[44] Watson GB. (2001). Actions of Insecticidal Spinosyns on $\gamma$-Aminobutyric Acid Responses from Small-Diameter Cockroach Neurons. Pesticide Biochemistry and Physiology, 71(1), 20-28.

[45] Perry T, McKenzie JA and Batterham PA. (2006). knockout strain of Drosophila melanogaster confers a high level of resistance to spinosad. Insect Biochem Mol Biol, 37,184-188.

[46] Amit S, Thompson G and Downard P. (2001). Challenges in implementing spinosad diamondback moth resistance management strategies in intensive vegetable growing areas in Asia. The management of diamondback moth and other crucifer pests, 313-318. 
[47] Herbert DA, Dugger P and Richter D. (1998). Evaluation of thrips damage on maturity and yield of Virginia cotton. Proc. Belt. Cott. Conf., California, USA, 2, 1177-1180.

[48] Leader A and Dutton R. (2002). Spinosad: A natural insecticide with novel mode of action for control of pests in UK field vegetable crops. In Proc. Int. BCPC Conf. Pests Diseases, Brighton, U.K, 237-242.

[49] Zezlina I and Blazic M. (2003). Testing the efficacy of different insecticides to control onion thrips (Thrips tabaci L., Thysanoptera: Thripidae). Communications in Agriculture Appl Bio Sci, 68(4a), 287-290.

[50] Kadam DR. (2006). Bioefficacy, persistence toxicity and residues of reduced risk insecticides against pomegranate thrips, Scirtothrips Dorsalis Hood. Agiricultural Entomology, Department Of Agril. Entomology, 1146.

[51] Dhanalakshmi DN and Mallapur CP. (2008). Evaluation of promising molecules against sucking pests of okra. Ann Pl Prot Sci, 16(1), 29-32.

\section{How to cite this article}

Sharawi S, Mahyoub J and Assagaf A. (2019). Laboratory evaluation of toxicity of spinosad tablets and tracer 48 SC insecticides against different stages of American cockroaches (Periplaneta americana L.), in Jeddah governorate. GSC Biological and Pharmaceutical Sciences, 6(1), 21-29. 